\title{
Sustainable Improvement of Residual Lateritic Soils Using Alum
}

\author{
Joshua Oluwasanmi Owoseni (Corresponding author) \\ Department of Applied Geology, Federal University of Technology, Akure, Nigeria \\ E-mail: joowoseni@ futa.edu.ng \\ Olabode O. Olofinyo \\ Department of Geology, University of Ibadan, Ibadan, Nigeria
}

\begin{abstract}
Cement stabilization has gained popularity in the tropics despite its known side effects. In Nigeria, a developing nation for instance, high cost and negative environmental impacts accompanying the use of cement constitute major drawbacks raising concerns. These shortcomings often make more sustainable alternatives necessary in a depressed economy. The current study explores the effects of alum on swelling potentials and strength of fine-grained Nigerian lateritic soils with a view to ascertaining the viability of the additive as cost-effective, eco-friendly and sustainable substitute for improving engineering properties of the soils as highway embankment or pavement materials. Particle-size analysis and Atterberg limits tests conducted according to British Standards (BS 1377) and ASTMD4318 respectively, aided in AASHTO classification of the un-treated soils as A-6 (clayey soil), A-4 (silty soil) and A-7-5 (clayey soil). These are poor to fair subgrade materials requiring stabilization. Similarly, high amounts of fines in the natural soils suggest susceptibility to recurring shrink and swell during alternating dry and wet seasons typical of tropical regions. However, alum-treated soils show reduction in plasticity with strong negative correlations. This implies reduction in swelling potentials and improvement in strength with alum treatment. Also, California bearing ratio (CBR) and shear strength, which followed the British Standards indicate strong positive correlations with alum content for the granite- and charnockite-derived soils. This indicates improved strength. Generally, the results suggest that alum has the potential to improve plastic fine-grained lateritic soils in line with the Federal Ministry of Works and Housing general specification for roads and bridges, with combined engineering, economic and environmental benefits.
\end{abstract}

Keywords: Additive, cement, embankment, highway, subgrade, soil stabilization, swelling soils

DOI: $10.7176 /$ JSTR/7-10-06

\section{Introduction}

Lateritic soils are common residual tropical weathering products abundantly developed over various rock types across wide geological terrains in Nigeria. Their wide distribution keeps them in high demand in the construction industry. However, reports show that they exhibit varying degrees of objectionable engineering properties which have necessitated modification of engineering properties of Nigerian soils to suit various construction and foundation uses. The deficiencies in engineering properties include excessive amounts of fines and the consequent high natural moisture content (Onuoha et al., 2014; Arumala and Akpokodje, 2016). This is against the backdrop of one of the major criteria for stability and suitability of lateritic soils for use as construction materials, that is, proper proportion of constituent clay-sized proportions (and clayey materials) which act as binder (Ackroyd, 1960). Besides, the sensitivity of these soils to moisture and resultant shrinking or swelling behaviour depends on the percentage of constituent clay-size fractions. Hence, some residual tropical soils were adjudged unsuitable as base course and subgrade materials for possessing high proportions of fines in parts of the region (Adeyemi and Oyeyemi, 2000; Onuoha et al., 2014; Arumala and Akpokodje, 2016). Failure of many engineering projects such as highway pavements, dams and buildings have been attributed to several geotechnical factors in different parts of the country (Akpokodje, 1986; Ademila, 2017; Adenika et al., 2018; Owoseni and Atigro, 2019). Therefore, the role of proper soil investigation

47 | $P$ a g e

www.iiste.org 
in engineering use of soils cannot be overemphasized. Where necessary, soils are stabilized to achieve some desirable engineering performance and optimal usefulness. Various researchers have attempted to stabilize engineering soils using mechanical methods (Yilmaz, 2015), chemical techniques (Arulrajah et al., 2017; Hassan et al., 2017; Latifi and Meehan, 2017; Rashid et al., 2017; Latifi et al., 2018), biological means (Lee et al., 2017; Dehghan et al., 2018; Hataf et al., 2018; Shankar et al., 2019) and electrical approaches (Tjandra and Wulandari, 2007; Hojati, 2017) for optimal use in various geotechnical construction works. Mechanical methods such as compaction produce increased soil strength, reduced compressibility, minimized volume change, lowered permeability and reduction in susceptibility to frost action. Chemical soil strengthening techniques sometimes take the form of mixing chemical additives with or injecting chemical substances into the soil. This approach of using chemical additives is still rated as the most common method of soil stabilization (Hataf et al., 2018).

From literature, the commonly used traditional chemical additives for soil strengthening include Portland cement, lime and bituminous materials (Joel and Agbede, 2010; Patel and Mishra, 2014; Mousavi and Sing, 2015; Pelliser et al., 2015; Hojati and Radlinska, 2017; Debnath and Dey, 2018). Cement has consistently gained global acceptance as chemical additive since its introduction as soil strengthener in the 1960s (Makusa, 2012; Chang et al., 2015; Al-Bared and Marto, 2017; Rashid et al., 2018). However, its negative environmental impacts which include emission of carbon-dioxide $\left(\mathrm{CO}_{2}\right)$, nitrous oxide $\left(\mathrm{NO}_{\mathrm{x}}\right)$ and particulate air (Chang et al., 2015; Hataf et al., 2018) are key shortcomings. These limitations often necessitate sustainable alternatives, especially in depressed economy like in Nigeria. In the last few decades, the feasibility of other maintainable alternatives to traditional chemical additives like cement has been an area of active research globally. Such researches are exploring ways of maximizing the use of available but objectionable soil resources for construction purposes by studying the viability of some common but cost-effective, eco-friendly and sustainable chemical additives as substitutes to the depleting and expensive traditional stabilizers (Rashid et l., 2017; Tabarsa et al., 2018; Yaghoubi et al., 2018).

More recently, the chemical additives which researchers have investigated for soil improvement include recycled tiles and tyres for concrete (Al-Bared et al., 2018; Al-Bared et al., 2018b), xanthan and guar gums for fine-grained collapsible soils (Chang et al., 2015; Dehghan et al., 2018), liquid polymer for tropical peat (Latifi et al., 2019) and, waste materials (Mujah et al., 2015; Ilies et al., 2017). Besides, agricultural wastes have also been evaluated for possible use as engineering soil stabilizers in some parts of the world (Chittaranjan, 2011). In Nigeria, the agricultural wastes which have been investigated for efficient, eco-friendly, cost-effective and sustainable improvement of tropical soils, groundnut shell ash (Oriola and Moses, 2010), coconut shell and husk ash (Amu et al., 2011), and, rice-husk ash (Owoseni and Atigro, 2014). In all these, the engineering performance of tropical soils was reportedly improved without any of the traditional additives. In the same vein, the current study examines the viability of alum as an alternative to the conventional stabilizers for sustainable tropical soil improvement for construction purposes in Nigeria. The work elucidates the effects of alum on the swelling potentials and strength characteristics of some lateritic soils as highway embankment and flexible pavement construction materials in Akure metropolis, southwestern Nigeria, where road failures have been persistently observed (Fig. 1).

\subsection{The study Area}

The study area, as shown in Fig. 2 (Federal Surveys Nigeria, 1966) lies within Latitudes $7^{\circ} 12^{\prime} \mathrm{N}$ and $7^{\circ} 19^{\prime} \mathrm{N}$ and Longitudes $5^{\circ} 08^{\prime} \mathrm{E}$ and $5^{\circ} 16^{\prime} \mathrm{E}$. The area has humid tropical climate of the West African monsoonal type, characterized by distinct wet and dry seasons. Annual rainfall sometimes rises to a mean value of about $1350 \mathrm{~mm}$ with high temperatures reaching a peak of about $32^{\circ} \mathrm{C}$ around February and a threshold of about $21^{\circ} \mathrm{C}$ around August. Relative humidity ranges from about $70 \%$ around January to about $90 \%$ in July. Both factors of rainfall and elevated temperature enhance the disintegration of rocks through chemical processes of weathering. The climate is considered the most important primary factor of lateritization; thus, Maignien (1966) suggested that contemporary lateritic soils have developed at mean annual temperatures of about $25^{\circ} \mathrm{C}$. Lateritic soils are generally believed to always correspond to climates in which the wet period is warm. Typically, the vegetation of the study area is the tropical rain forest with thick undergrowth but had in many parts been modified by human activities such as urbanization, construction, land cultivation and deforestation (Maignien, 1966).

48 | $\mathrm{P}$ a g e

www.iiste.org 


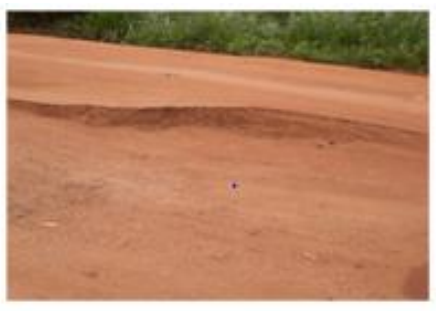

(i)

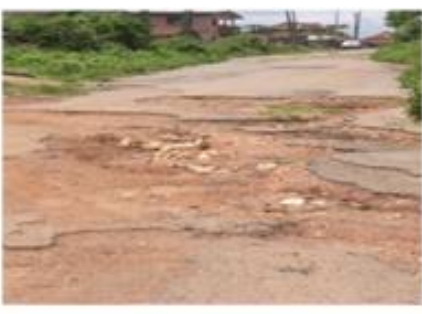

(ii)

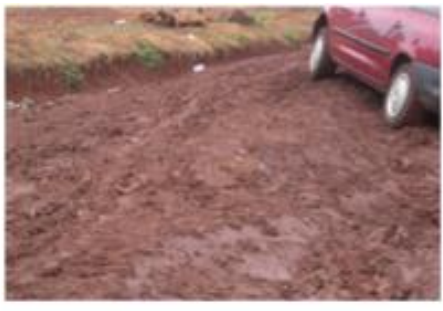

(iii)

Figure 1. Failed sections of pavements in Akure, adjacent to sampling points (i) S1 (ii) S2 (iii) S3

\subsection{Geological Setting}

The area under investigation lies within the Precambrian Basement Complex (PBC) of Nigeria. Researchers have variedly classified the assemblages of the PBC into four lithological groups, viz: minor intrusives, Older granites, schist belts and migmatite-gneiss-quartzite complex (Oyinloye and Odeyemi, 2001; Anifowose and Borode, 2007). The most prominent of these lithologic units in the study area are the minor intrusive rocks, the Older granites and the migmatite-gneiss-quartzite complex (Fig. 3) (Nigeria Geological Survey Agency, 2006). Granite, gneisses and charnockites (from Oba-Ile area, Oke-Aro and Ire-Akari areas respectively) constitute the local geology in the study area. The rock assemblages vary texturally from medium to coarse (porphyritic) grains. Generally, the fissure zones trend NS while the foliation trends are NNW-SSE and NNE-SSW (Olorunfemi et al., 1999).

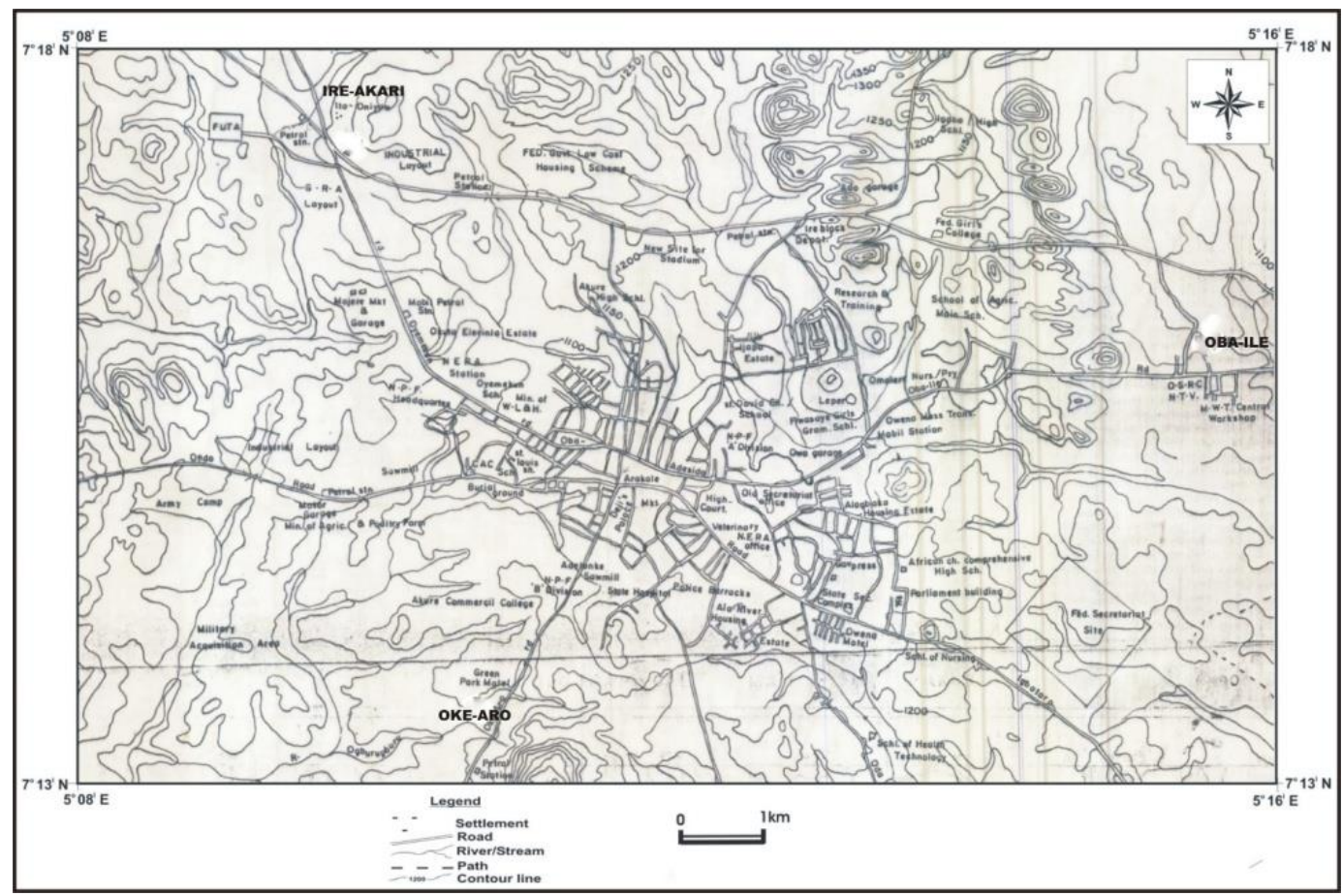

Figure 2. Topographic map of Akure environs (Federal Surveys Nigeria, 1966) 


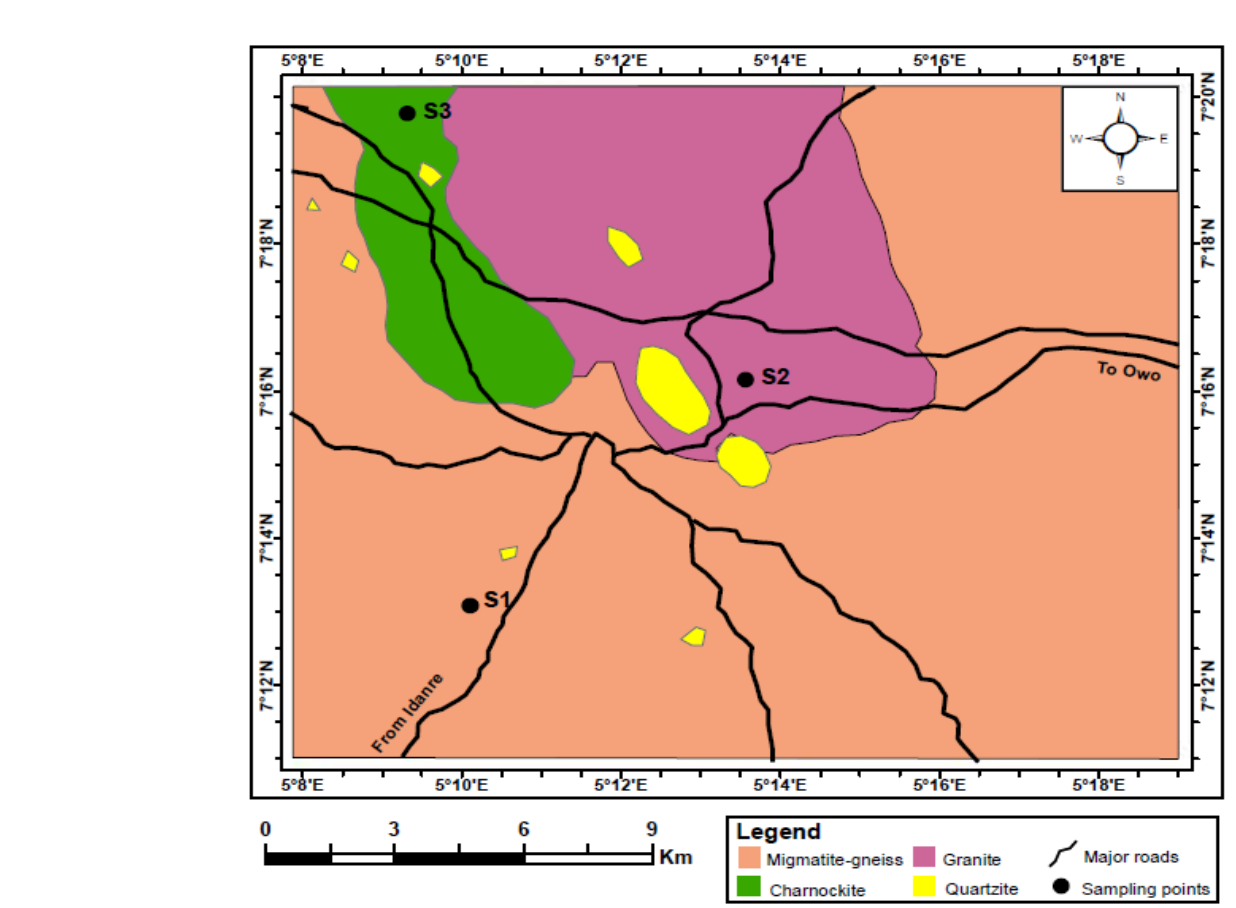

Figure 3. Geological map of Akure (Modified after Nigeria Geological Survey Agency, 2006)

\section{Materials and methods}

\subsection{Residual lateritic soil}

Three disturbed representative bulk samples of granite-, charnockite-, and migmatite-gneiss-derived lateritic soils were collected at depth of $1.0 \mathrm{~m}$ below the ground surface, and were air-dried under laboratory conditions for 7 days.

\subsection{Dissolve alum}

The alum used for treating the soils was sourced locally from a market in Akure metropolis. In chemical terms, alum is a group of double salts that contain aluminum sulphate coupled with potassium or ammonium sulphate. It is a water-soluble mineral with density of about 1.76 and is commonly used in water treatment due partly to its solubility in water. It used to be a raw material in the textile industry as a mordant or fixing agent for holding natural dyes to fabrics. It has also been applied to improve the physical properties of potting media and to act as liming material (Bugbee and Frink, 2006). It has been shown to be effective in improving soil aggregate stability and decreasing aggregate rupture stress (Eltaif and Gharaibeh, 2008).

\subsection{Sample Preparation}

The potash alum used as additive was pulverized after which wet mixing was done. Specified amounts $(5,10$, and $15 \mathrm{~g} / \mathrm{l})$ of the pulverized alum were first dissolved in distilled water to give hydro-solution. Thereafter, the dissolved alum solutions were mixed in turn with soil samples at room temperature. The mixing was done by hand to ensure proper soil-alum-water admixture. This procedure was repeated for all the soil samples for the different dosages of the additive.

\subsection{Test Procedure}

For the un-treated soils, air-dried samples were used for the consistency limits tests. To further investigate the plasticity and strength characteristics of the soil-water-alum admixture, three basic engineering tests were conducted, viz: consistency limits, CBR and Triaxial unconsolidated-undrained tests. The consistency limits tests followed the ASTM-D4318 specifications while the CBR and triaxial tests were conducted in accordance with the British standard, BS 1377 (1990) specifications. For the triaxial unconsolidated-undrained test, confining pressures of 100, 200 and $300 \mathrm{kPa}$ were applied. 


\subsection{Data Analysis}

The geotechnical data obtained from the laboratory analyses were subjected to univariate and bivariate statistical treatments. Results of statistical data analysis were presented as scatter plots and graphical regression lines. The effects of the stabilizer on the geotechnical properties of the residual soils were further understood and quantitative relationships between plasticity index, CBR and shear strength, and varying amounts of alum were established.

\section{Results and Discussion}

\subsection{Some geotechnical properties of un-stabilized soils}

The results of the laboratory geotechnical analyses on the un-stabilized soil samples are summarized in Tables 1 and 2 .

\subsubsection{Soil classification}

The results of particle-size distribution analysis of the un-treated soils (Table 1) showed that migmatitegneiss-derived soil (S1) has the least amounts of fines $(56.30 \%)$ and highest coarse fractions $(43.70 \%)$. The charnockite-derived soil (S3) exhibited the highest amounts of fines and the least coarse fractions $(96.10 \%$ and $3.90 \%$ respectively). For the granite-derived soil (S2), the values are relatively intermediate $(75.80 \%$ fine and $24.20 \%$ coarse fractions respectively). These wide variations in particle distributions reflect the mineralogy and textural characteristics of the parent rocks. The high amounts of fines suggest that the three soils are susceptible to recurrent shrink and swell during alternating dry and wet seasons characteristic of the tropics (Ademila, 2017). None of the un-treated soils meet the Nigerian specifications of $\leq 15 \%$ fines for base course materials or $\leq 35 \%$ fines for embankment and general filling purposes. Based on the particle-size distributions, liquid limit and plasticity index characteristics, the un-treated migmatite-gneiss-, granite- and charnockite-derived soil samples fall into groups A-6 (clayey soil), A-4 (silty soil) and A-7-5 (clayey soil) of the AASHTO classification system. This implies that the soils are fair to poor subgrade materials which would require special treatment to meet the requirements for subgrade materials in highway construction. Hence, the need for stabilizing the soils.

\subsubsection{Natural moisture content and specific gravity}

As expected, the clayey charnockite-derived soil with the highest amounts of clay-sized fractions, exhibited the highest natural moisture content value $(22.2 \%)$ which exceeds the $5-15 \%$ specified for engineering construction in Nigeria (Federal Ministry of Works and Housing, 2000). This suggests high water absorption tendency for the soil. Next ranked in natural moisture content $(14.19 \%)$ is the clayey migmatite gneiss-derived soil with medium clay-sized fractions. The silty granite-derived soil with the lowest proportion of clay-sized particles indicated the least moisture content $(5.09 \%)$. The moisture contents of the migmatite-gneiss- and granite-derived soils fall within the Nigerian specification. These wide-ranging moisture content values reflect differences in clay mineralogy and textural characteristics of the parent rocks. Also, the specific gravity of the soils varied from 2.64 to 2.70. Since the degree of soil maturity is directly related to specific gravity, the migmatite-gneiss-derived soil with the highest specific gravity value (2.70) is the most matured and lateritized while the charnockite-derived soil with the lowest value (2.64) may have undergone the least degree of lateritization.

Table 1. Results for particle size distribution and specific gravity of the un-stabilized soils

\begin{tabular}{llllll}
\hline Sample no. & Parent Rock & $\begin{array}{l}\text { Specific } \\
\text { gravity }\end{array}$ & \% Gravel & \% Sand & \% Fine \\
\hline S1 & Migmatite & 2.70 & 9.08 & 34.65 & 56.27 \\
S2 & Gneiss & & & & \% silt + clay \\
S3 & Granite & 2.65 & 0.57 & 23.65 & 75.78 \\
\hline
\end{tabular}

$\mathbf{5 1} \mid \mathrm{P}$ a g e 


\subsubsection{Plasticity characteristics}

The liquid limit (LL) and plasticity index (PI) values for the soil samples varied from 20.40 to 48.78 and 5.40 to 20.87 respectively (Table 2 ). Only the silty granite-derived soil (with LL $=20.40$ and PI $=$ 5.40) meet the Nigerian specification of $\mathrm{LL} \leq 30$ and $\mathrm{PI} \leq 13$ for base course materials. Hence, soil stabilization is necessary for the clayey migmatite-gneiss- and charnockite-derived soils. From the liquid limit values, the un-treated granite-derived soil ( $\mathrm{S} 1$ with $\mathrm{LL}=20.40)$ is non-plastic while the migmatite- and charnockite-derived soils (S2 and S3 with LL $=35.85$ and 48.78 respectively) possess intermediate plasticity (Table 3) (Bell, 2007). The plasticity index values for the un-treated soils varied from 5.40 to $20.87 \%$. According to Ola (1981) who classified swelling potential based on plasticity index values (Table 4), the granite-derived soil (S1) exhibited low swelling potential while the migmatite-gneiss- and charnockite-derived soils (S2 and S3 respectively) possessed medium swelling potentials.

\subsubsection{Strength characteristics}

\subsubsection{California Bearing Ratio (CBR)}

The results of California bearing ratio (CBR) test often indicate suitability or otherwise of engineering soils in road construction as base course, subbase and subgrade materials (Ademila, 2017). The unsoaked CBR $(30 \%, 66 \%, 14 \%)$ for S1, S2 and S3 respectively (Table 2) all fall below the required $80 \%$ minimum value recommended for highway subgrade and subbase soils by the Federal ministry of works and housing (FMWH, 2000) (Table 8). According to FMWH specification, both S1 and S2 are suitable as base course materials while S3 falls short of the required minimum value of $25 \%$.

\subsubsection{Unconfined Compressive Strength (UCS)}

The results of unconsolidated undrained test give clue on the consistency of the clayey soils in terms of unconfined compressive strengths, thus indicating the performance of the soils as engineering foundation materials (Ademila, 2017). The Unconfined Compressive Strength (UCS) values obtained for migmatite-gneiss-, granite-, and charnockite-derived soils are $69.82 \mathrm{kPa}, 23.95 \mathrm{kPa}$ and $101.71 \mathrm{kPa}$ respectively (Table 2). According to Das (2000), these values indicate medium, very soft and stiff consistency classes respectively (Table 5). These are indications of poor subgrade materials liable to pavement failure and requiring some sorts of improvements for better engineering performance.

\subsubsection{Shear strength}

For the triaxial unconsolidated-undrained test, confining pressures of 100, 200 and $300 \mathrm{kPa}$ were applied to determine the stress-strain characteristics and shear strengths of soils. The test results (Table 2) show low cohesion $(39.50 \mathrm{kPa}-64.20 \mathrm{kPa})$ and angles of internal friction $\left(14.80^{\circ}-24.10^{\circ}\right)$.

Table 2. Summary of the geotechnical properties of un-stabilized soils

\begin{tabular}{|c|c|c|c|c|c|c|c|c|c|c|c|c|}
\hline \multirow{2}{*}{$\begin{array}{l}\text { Sample } \\
\text { No. }\end{array}$} & \multirow{2}{*}{$\begin{array}{l}\text { Parent } \\
\text { Rock }\end{array}$} & \multirow{2}{*}{$\begin{array}{l}\mathbf{M}_{\mathbf{c}} \\
(\%)\end{array}$} & \multirow{2}{*}{$\begin{array}{l}\text { LL } \\
(\%)\end{array}$} & \multirow{2}{*}{$\begin{array}{l}\text { PL } \\
(\%)\end{array}$} & \multirow{2}{*}{$\begin{array}{c}\text { PI } \\
(\%)\end{array}$} & \multirow{2}{*}{$k(\mathrm{~m} / \mathrm{s})$} & \multirow{2}{*}{$\begin{array}{c}\text { CBR } \\
(\%)\end{array}$} & \multirow{2}{*}{$\begin{array}{c}\text { UCS } \\
(\mathbf{k P a})\end{array}$} & \multicolumn{2}{|c|}{ Compaction } & \multicolumn{2}{|c|}{ Triaxial } \\
\hline & & & & & & & & & $\begin{array}{c}\text { OMC } \\
(\%)\end{array}$ & $\begin{array}{c}\text { MDD } \\
\left(\mathrm{Kg} / \mathrm{m}^{3}\right)\end{array}$ & $\begin{array}{c}\mathrm{C}_{\mathrm{u}} \\
(\mathrm{kPa})\end{array}$ & $\varphi_{u}\left(^{0}\right)$ \\
\hline S1 & $\begin{array}{l}\text { Migmatite } \\
\text { Gneiss }\end{array}$ & 14.19 & 35.85 & 20.83 & 15.02 & 0.36 & 30 & 69.82 & 16.40 & 1745 & 43.80 & 24.10 \\
\hline S2 & Granite & 5.09 & 20.40 & 15.00 & 5.40 & 0.29 & 66 & 23.95 & 9.60 & 1958 & 39.50 & 14.80 \\
\hline S3 & Charnockite & 22.20 & 48.78 & 27.91 & 20.87 & 0.15 & 14 & 101.71 & 26.50 & 1559 & 64.20 & 16.30 \\
\hline
\end{tabular}

$M_{\mathrm{c}}$ natural moisture content; $L L$ liquid limit; $P L$ plastic limit; $P I$ plasticity index; $k$ hydraulic conductivity; $\tau$ shear strength; $O M C$ optimum moisture content; $M D D$ maximum dry density; $C B R$ California bearing ratio; UCS unconfined compressive strength. 
Table 3. Relating liquid limit to plasticity of soils (Bell, 2007)

\begin{tabular}{lll}
\hline Liquid limit (\%) & Plasticity & Results \\
\hline$<35$ & Low & S2 (20.40) \\
$35-50$ & Intermediate & S1 (35.85), S3 (48.78) \\
$50-70$ & High & Nil \\
$70-90$ & Very high & Nil \\
$>90$ & Extra high & Nil \\
\hline
\end{tabular}

Table 4 Relating plasticity index to swelling potential of soils (Ola, 1981])

\begin{tabular}{lll}
\hline Plasticity Index & Swelling potentials & Results \\
\hline $0-15$ & Low & S2 (5.40) \\
$15-25$ & Medium & S1 (15.02), S3 (20.87) \\
$25-35$ & High & Nil \\
$>35$ & Very high & Nil \\
\hline
\end{tabular}

Table 5 Relating Unconfined Compressive Strength to consistency of soils (Das, 2000)

\begin{tabular}{lll}
\hline $\begin{array}{l}\text { Unconfined Compressive } \\
\text { Strength (kPa) }\end{array}$ & Consistency & Results \\
\hline $0-25$ & Very soft & S2 (23.95) \\
$25-50$ & Soft & Nil \\
$50-100$ & Medium & S1 (69.82) \\
$100-200$ & Stiff & S3 $(101.71)$ \\
$200-400$ & Very stiff & Nil \\
$>400$ & Hard clay & Nil \\
\hline
\end{tabular}

\subsection{Effects of alum on stabilized soils}

The results of the laboratory geotechnical analyses on the alum-stabilized soil samples are summarized in Tables 6. The geotechnical data are further subjected to statistical analysis and the descriptive statistics presented in Table 7. The standard deviation (SD) shows the measure of variability for each single data set. The degree of dispersion among the variables measured in different units is better understood from the coefficient of variation $(\mathrm{CV})$. The results show that unconfined compressive strength (UCS) and liquid limit (LL) have the highest and least CV (105.45 and $33.21 \%$ ) respectively. These indicate that the data points for UCS are spread out over the largest range of values while the data points for LL tend to be the closest to the mean.

\subsubsection{Plasticity and swelling characteristics}

The results of Atterberg limit tests (Table 6) conducted on alum-stabilized soil samples showed that addition of 5\% alum produces a drastic reduction in plasticity of the three soils while the reducing effect was progressively more or less gradual on addition of $10 \%$ and $15 \%$ alum content in turn. For the migmatite-gneiss-derived soil, the Liquid limits (LL) reduced drastically from $35.85 \%$ (un-stabilized state) to $24.89 \%$, then steadily to $24.25 \%$ and finally to $20.59 \%$ with 5,10 and $15 \mathrm{~g} / 1$ alum contents respectively. The plasticity index (PI) dropped appreciably from 15.02 (for the un-stabilized state) to 11.08 (26.23\% reduction), then steadily to 9.65 (35.75\% reduction) and further to $8.69(42.14 \%$ reduction) when treated with 5,10 and $15 \mathrm{~g} / \mathrm{l}$ alum content respectively. Here, there are indications that the geotechnical performance with respect to plasticity, was improved upon from medium to low plasticity with the addition of alum. Also, for the granite-derived soil, the PI reduced drastically from 5.40 for the natural soil to progressively increasing non-plastic state with increased alum content $(0 \%$

53 | P a g e

www.iiste.org 
through $10 \%$ to $15 \%)$.

Table 6. Summary of consistency limits, CBR and UCS tests for alum-stabilized soils

\begin{tabular}{lllllll}
\hline Sample no. & $\begin{array}{l}\text { Alum content } \\
(\mathbf{g} / \mathbf{l})\end{array}$ & $\begin{array}{l}\text { LL } \\
\mathbf{( \% )}\end{array}$ & PL (\%) & $\begin{array}{l}\text { PI } \\
(\mathbf{\%})\end{array}$ & $\begin{array}{l}\text { CBR } \\
(\mathbf{\%})\end{array}$ & $\begin{array}{l}\text { Shear Strength } \\
(\mathbf{k P a})\end{array}$ \\
\hline S1 & 0 & 35.85 & 20.83 & 15.02 & 30.00 & 34.91 \\
& 5 & 24.89 & 13.81 & 11.08 & 26.00 & 13.97 \\
& 10 & 24.25 & 14.60 & 9.65 & 23.00 & 12.89 \\
& 15 & 20.59 & 11.90 & 8.69 & 22.00 & 9.24 \\
S2 & 0 & 20.40 & 15.00 & 5.40 & 66.00 & 11.98 \\
& 5 & 14.80 & 29.30 & $\mathrm{NP} *$ & 71.00 & 13.81 \\
& 10 & 18.70 & 28.70 & $\mathrm{NP} *$ & 73.00 & 13.97 \\
& 15 & 29.50 & 30.30 & $\mathrm{NP} *$ & 76.00 & 14.85 \\
S3 & 0 & 48.78 & 27.91 & 20.87 & 14.00 & 50.86 \\
& 5 & 29.81 & 13.95 & 15.86 & 19.00 & 93.17 \\
& 10 & 30.35 & 16.80 & 13.55 & 17.00 & 46.73 \\
& 15 & 27.69 & 14.90 & 12.79 & 26.00 & 136.50 \\
\hline
\end{tabular}

* NP non-plastic CBR California bearing ratio; UCS unconfined compressive strength; kPa kilopascal

Table 7. Descriptive statistics of geotechnical data for alum-stabilized soils

\begin{tabular}{llllllll}
\hline Variable & Units & $\mathbf{n}^{\mathbf{a}}$ & Min. & Max. & Mean & SD & CV (\%) \\
\hline LL & $\%$ & 12 & 14.80 & 48.78 & 27.13 & 9.01 & 33.21 \\
PL & $\%$ & 12 & 11.90 & 30.30 & 19.83 & 7.15 & 36.06 \\
PI & $\%$ & 12 & 0.00 & 20.87 & 12.55 & 4.53 & 36.10 \\
CBR & $\%$ & 12 & 14.00 & 76.00 & 38.58 & 24.77 & 64.20 \\
UCS & $\mathrm{kPa}$ & 12 & 18.47 & 273.10 & 75.47 & 79.58 & 105.45 \\
\hline
\end{tabular}

LL liquid limit, PL plastic limit, PI plasticity index, CBR California bearing ratio, UCS unconfined compressive strength, $\mathrm{n}^{\mathrm{a}}$ number of samples, Min minimum, Max maximum, SD standard deviation, $\mathrm{CV}$ coefficient variation.

Moreover, the LL for the charnockite-derived soil dropped considerably from 48.78 (for un-stabilized state) to 29.81 (38.89\% drop), picked a little up to 30.35 (37.78\% drop) and fell again to 27.69 (43.23\% fall) when stabilized with 5,10 and $15 \mathrm{~g} / 1$ alum content respectively. PI reduced from 20.87 (for unstabilized state) to 15.86 (24.01\% reduction), 13.55 (35.07\% reduction) and 12.79 (38.72\% reduction) with 5,10 and $15 \mathrm{~g} / 1$ alum content respectively (Figure 4a). Here also, the soil improved from medium plasticity to low plasticity. Furthermore, the study reveals very strong negative correlations of -0.95 , 0.77 and -0.92 between alum content and PI for gneiss-, granite-, and charnockite-derived soils respectively (Figures $4 \mathrm{~b}$ ). The results of consistency limits indicate that the dissolved alum content of $5-15 \%$ improved the plasticity characteristics of the investigated soils.

In all, the addition of alum improved the engineering geological properties of the soil samples, especially by significantly reducing their plasticity indices, an indication of reduction in swelling potential which could translate to an increase in strength characteristics. 


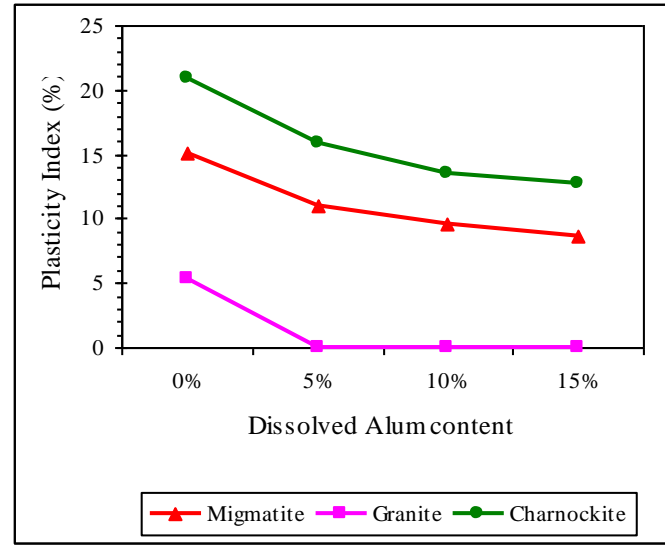

(a)

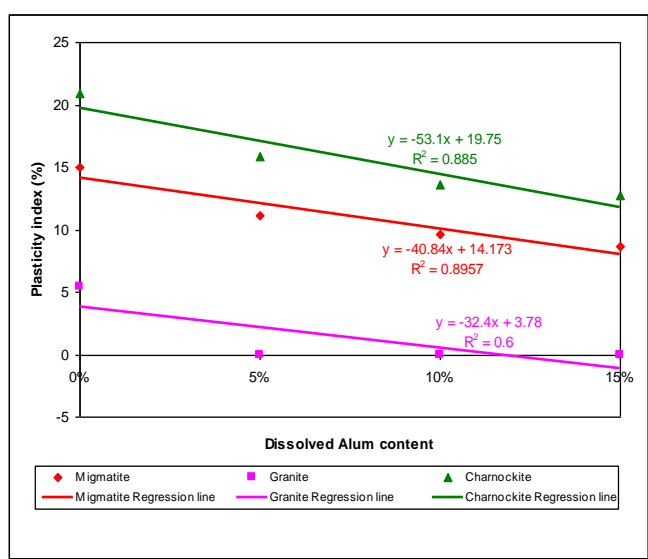

(b)

Figure 4. Effects of varied proportions of alum on different soil samples (a) Relative reduction in Plasticity Indices (b) Regression lines of Plasticity indices with Alum contents

\subsubsection{Strength Characteristics}

\subsubsection{California Bearing Ratio (CBR)}

Generally, the results of CBR tests (Table 6) indicate that addition of dissolved alum has positive effects (CBR increase) on the granite- and charnockite-derived soils while the effect on migmatitegneiss-derived soils is rather adverse, resulting in CBR reduction (Figure 5a). For the granite-derived soil, the CBR rose drastically by $5 \%$ (from $66 \%$ for un-stabilized soil to $71 \%$ ), then dropped gradually by $2 \%$ (to $73 \%$ ) and finally rose again to $76 \%$ with dissolved alum content of 5,10 and $15 \mathrm{~g} / 1$ respectively. Moreover, for the charnockite-derived soil, the CBR increased from 14\% for un-stabilized soils to $19 \%, 17 \%$ and $26 \%$ with dissolved alum content of 5, 10 and $15 \mathrm{~g} / 1$ respectively. However, for the migmatite-gneiss-derived soil, the CBR value reduced from $30 \%$ for un-stabilized soil to $26 \%, 23 \%$ and $22 \%$ with dissolved alum content of 5, 10 and $15 \mathrm{~g} / \mathrm{l}$ respectively. This study reveals very strong positive correlations $(0.98$ and 0.86$)$ between alum content and CBR for the granite- and charnockitederived soils respectively. However, there is a negative correlation $(-0.97)$ between alum content and CBR for the gneiss-derived soil (Figure 5b). From the foregoing, dissolved alum (about 5-15\%) may be adjudged suitable for both the granite- and charnockite-derived soils while other stabilizing agents may be used for the migmatite-gneiss-derived soil. The results also indicated that load bearing capacity increased when dissolved alum was added to both granite- and charnockite-derived soil samples. This load bearing capacity (or ratio) would increase the longevity of road, improve the soil aggregate stability and decrease aggregate rupture stress.

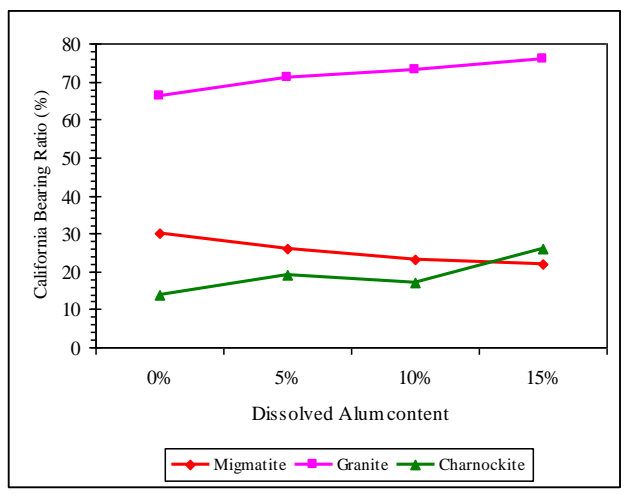

(a)

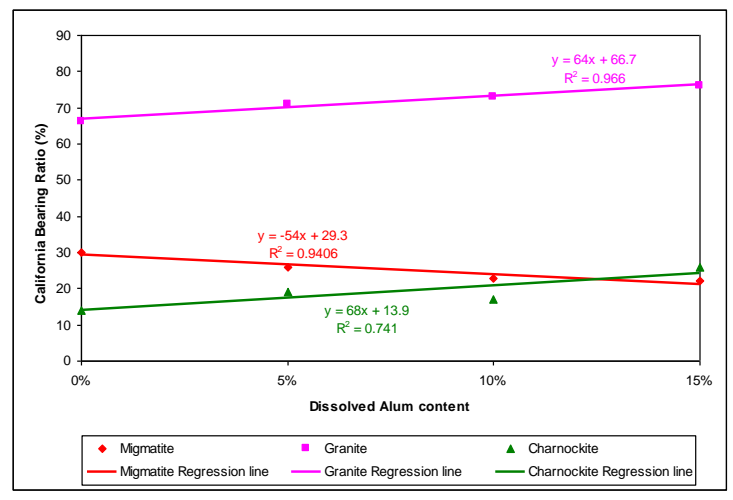

(b)

Figure 4. Effects of varied proportions of alum on different soil samples (a) Relative increment in CBR (b) Regression lines of CBR with Alum contents

\subsubsection{Shear Strength}

55 | $\mathrm{P}$ a g e

www.iiste.org 
Table 4 shows the variation of Shear strength with dissolved alum content for the soils investigated. It is obvious from Fig. 5a that increasing dissolved lime has pronounced positive effect (increase in shear strength) on the charnockite-derived soil, and moderately positive effect on the granite-derived soil, while the effect is adversely negative (reduction in shear strength) on the migmatite-gneiss-derived soil. For the granite-derived soil the shear strength rose from $11.98 \mathrm{Kpa}$ for unstabilized granite-derived soils to $13.81,13.97$, and $14.85 \mathrm{Kpa}$ with dissolved alum content of 5, 10 and $15 \mathrm{~g} / \mathrm{l}$, implying $15.28 \%$, $16.61 \%$, and $23.96 \%$ strength improvement respectively. Also, for the charnockite-derived soil, the shear strength improved drastically from $50.86 \mathrm{Kpa}$ (unstabilized state) to $93.17 \mathrm{Kpa}$, dropped to $46.73 \mathrm{Kpa}$, and sky-rocketed again to $136.50 \mathrm{Kpa}$ with dissolved alum content of 5 , 10 and $15 \mathrm{~g} / 1$ respectively. However, for the gneiss-derived soil, the shear strength reduced from $34.91 \mathrm{Kpa}$ to $13.97 \mathrm{Kpa}$, then fell further to $12.89 \mathrm{Kpa}$ and then to $9.24 \mathrm{Kpa}$ with dissolved alum content of 5,10 and $15 \mathrm{~g} / 1$ respectively. Figure $5 \mathrm{~b}$ shows the improvement in shear strength of the granite- and charnockitederived soils with positive correlations of 0.94 and 0.65 respectively between alum content and shear strength. In contrast however, the shear strength was worsened with a negative correlation of -0.87 between alum content and shear strength for the gneiss-derived soil. Summarily, the addition of alum has improved the shear strength characteristics of both the granite- and charnockite-derived soils appreciably.

\section{Conclusion}

This study investigated the viability of alum as potential alternative soil additive to cement for improved soil engineering performance with benefits of eco-friendliness, cost-effectiveness and sustainability. Laboratory investigations which include Atterberg limits, California bearing ratio and triaxial tests were conducted for residual lateritic soils on different crystalline basement rocks in southwestern Nigeria. The effects of alum on the swelling potentials and strength properties of the soils were investigated for use highway embankment construction materials in Nigeria. The following conclusions can be drawn based on the study:

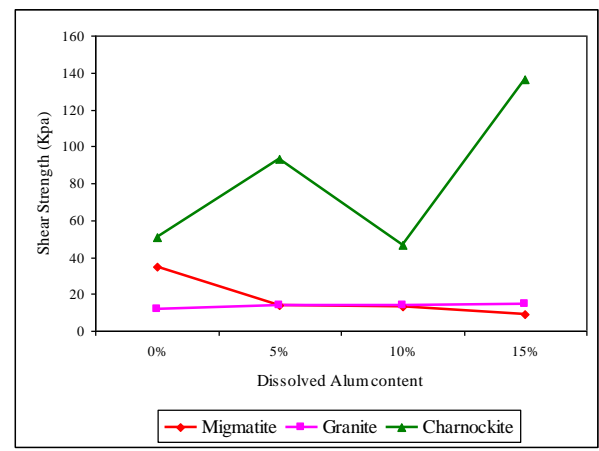

(a)

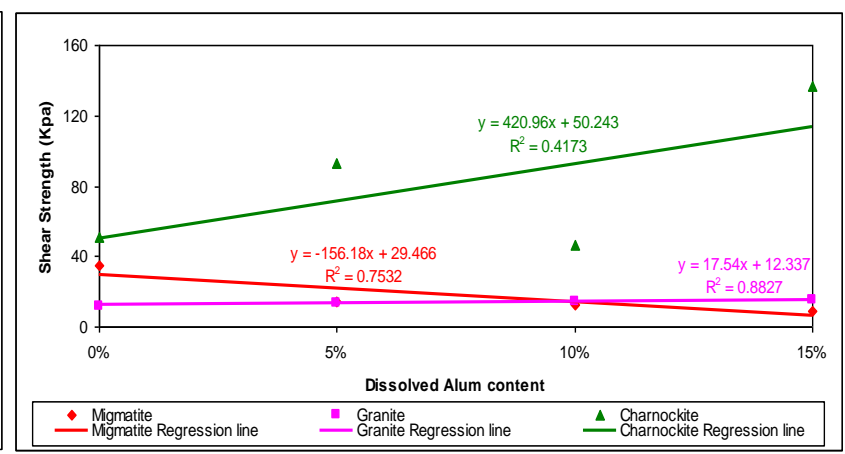

(b)

Figure 5. Effects of varied proportions of alum on different soil samples (a) Relative increment in Shear strength (b) Regression lines of Shear strength with Alum contents

1. The addition of alum reduced the plasticity of the gneiss- and charnockite-derived soils by $26.23-$ $42.14 \%$ and $24.01-38.72 \%$ respectively. There were strong negative correlations $(-0.95,-0.77$ and 0.92 respectively) between alum contents and plasticity indices. Significant reduction in plasticity indices implied reduction in swelling potential and hence an increase in strength properties.

2. The California bearing ratio (CBR) of alum treated granite- and charnockite-derived soils increased by $5-10 \%$ and $5-12 \%$ respectively. Strong positive correlations ( 0.98 and 0.86 respectively) were also established. The observed improvement in load bearing capacity indicates higher strength which would enhance longevity of road and stability of soil aggregates under vehicular load. 
3. The shear strengths of treated granite- and charnockite-derived soils improved by $15.28-23.96 \%$ and $83.19-168.38 \%$ respectively. Strong positive correlations were obtained between alum content and shear strengths of treated soils ( 0.94 and 0.65 respectively).

Generally, the results suggest that alum has the potential to improve plastic fine-grained lateritic soils in line with the Federal Ministry of Works and Housing general specification for roads and bridges (Table 8), with combined engineering, economic and environmental benefits. Hence, alum improved the swelling and strength properties of the residual soils. Hence, alum can be adjudged a viable substitute for stabilizing the granite- and charnockite-derived soils in Akure for use in highway embankment and pavement construction with combined engineering, economic and environmental benefits. 


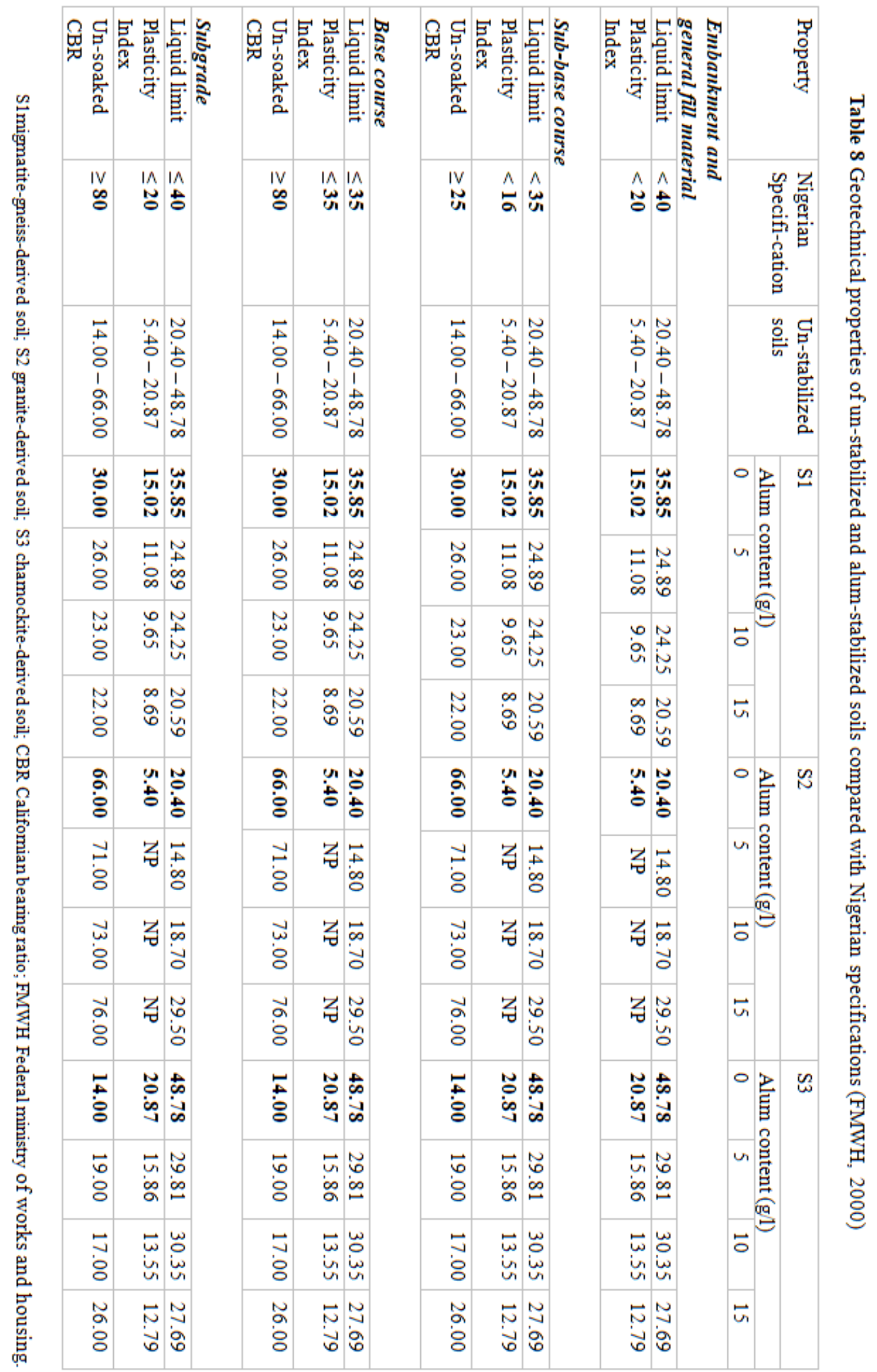




\section{References}

Ackroyd, I. W. (1960) Notes on crushing strength of some western Nigerian concretionary gravels and their selection for use as building material. Min. Transp., Ibadan W. Nigeria, Tech. Paper, 6.

Ademila, O. (2017) Engineering evaluation of lateritic soils of failed highway sections in southwestern Nigeria. Geosciences Research. 2(3):210-218.

Adenika, C. I., Ariyibi, E. A., Awoyemi, M. O., Adebayo, A. S., Dasho, O. A., Olagunju, E. O. (2018) Application of geophysical approach to highway pavement failure: a case study from basement complex terrain southwestern Nigeria. Int. Jour. of Geo-Eng. 9(8):1-22.

Adeyemi, G. O., Oyeyemi, F. (2000) Geotechnical basis for failure of sections of the Lagos-Ibadan expressway, south western Nigeria. Bull. Eng. Geol. Env. 59:39-45.

Akpokodje EG (1986) The geotechnical properties of lateritic and non-lateritic soils of southeastern Nigeria and their evaluation for road construction. Bulletin of the international association of Engineering Geology. 3:115-121.

Al-Bared MAM, Marto A (2017) A review on the geotechnical and engineering characteristics of marine clay and the modern methods of improvements. Malaysian J Fundam Appl Sci 13:825831

Al-Bared, MAM., Marto, A. and Latifi, N. 2018. Utilization of recycled tiles and tyres in stabilization of soils and production of construction materials - A state-of-the-art review. KSCE Journal of Civil Engineering, 22(10), 3860-3874.

Al-Bared, MAM., Marto, A., Latifi, N. and Horpibulsuk, S. 2018. Sustainable improvement of marine clay using recycled blended tiles. Geotechnical and Geological Engineering, 36(5), 3135-3147.

Amu, OO., Owokade, OS., and Shitan, OI. 2011. Potentials of Coconut shell and husk ash on the geotechnical properties of lateritic soil for road works. Int. Jour. Eng. and Tech. 3(2), 87-94.

Anifowose, AYB. and Borode, AM. 2007. Photogeological study of the fold structure in Okemesi area, southwestern Nigeria. Jour. Min. Geo. 43(2), 125-130.

Arulrajah A, Kua TA, Suksiripattanapong C, Horpibulsuk S (2017) Stiffness and strength properties of spent coffee grounds-recycled glass geopolymers. Road Mater Pavement Des. https://doi.org/10.1080/14680629.2017.1408483

Arumala JO, Akpokodje EG (2016) Soil properties and pavement performance in the Niger Delta. Quarterly J. of Engineering Geology. 20:287-296.

ASTM-D4318 Standard Test Methods for Liquid Limit, Plastic Limit, and Plasticity Index of Soils

Bell FG (2007) Engineering geology, $2^{\text {nd }}$ Ed. Butterworth-Heinmann Publishers, Oxford.

BS (British Standards Institutions 1377). 1990. Methods of tests for soils for Civil Engineering purposes. General requirements and sample preparation. London, p. 38.

Bugbee, GJ. and Frink, CR. 2006. Alum sludge as a soil amendment: Effects on soil properties and plant growth. CABI Retrieved from http://www.cabaabstractsplus. org/abstracts/ Abstract.aspx?Ac-No=19861905544.

Chang, I., Im, J., Prasidhi, AK. and Cho, GC. (2015) Effects of Xanthan gum biopolymer on soil strengthening. Constr. Build. Mater. 74:65-72.

59 | P a g e

www.iiste.org 
Chittaranjan, M., Vijay, M. and Keerthi, D. 2011. Agricultural wastes as soil stabilizers. Int. Jour. Earth Sci. and Eng., 4(6), 50-51.

Debnath, P. and Dey, A. 2018. Prediction of bearing capacity of geogrid-reinforced stone columns using support vector regression. Int. J. Geomech. 18(2):04017147.

Dehghan H, Tabarsa A, Latifi N, Bagheri Y (2018) Use of xanthan and guar gums in soil strengthening. Clean Technologies and Environmental Policy, 21(1), 155-165.

Eltaif, NI. And Gharaibeh, MA. 2008. Impact of alum on crust prevention and aggregation of calcareous soil: Laboratory studies. Soil Use Manage. 24(4): 424-426.

Federal Ministry of Works and Housing (2000) General specification for roads and bridges. 2:137275.

Federal Surveys, Nigeria (1966) Topographical Sheet, 1:50,000, Akure S.W. Sheet 624 S.W.

Hassan WHW, Rashid ASA, Latifi N, Horpibulsuk S, Borhamdin S (2017) Strength and morphological characteristics of organic soil stabilized with magnesium chloride. Q J Eng Geol Hydrogeol 50(4):454-459

Hataf, N., Ghadir, P. and Ranjbar, N. 2018. Investigation of soil stabilization using chitosan biopolymer. J. Clean Prod. 170:1493-1500.

Hojati M (2017) Shrinkage and creep of alkali-activated binders. Doctoral dissertation, Pennsylvania State University

Hojati, M. and Radlinska, A. 2017. Shrinkage and strength development of alkali-activated fly ashslag binary cements. Constr. Build. Mater. 150:808-816.

Ilies, NM., Circu, AP., Nagy, AC., Ciubotaru, VC. and Kisfaludi-Bak, Z. 2017. Comparative study on soil stabilization with polyethylene waste materials and binders. Procedia Eng. 181:444-451.

Joel, M., and Agbede, IO. 2010. Cement stabilisation of Igumale shale lime admixture for use as flexible pavement construction material. Electronic Journal of Geotechnical Engineering. 15: 1661-1673.

Latifi N, Meehan CL (2017) Strengthening of montmorillonitic and kaolinitic clays with calcium carbide residue: a sustainable additive for soil stabilization. In: Geochemical frontiers, pp 154163

Latifi, N., Siddiqua, S., \& Marto, A. 2019. Stabilization of Tropical Peat Using Liquid Polymer. In The International Congress on Environmental Geotechnics (pp. 826-833). Springer, Singapore.

Latifi, N., Vahedifard, F., Ghazanfari, S. and Rashid, A. 2018. Sustainable usage of calcium carbide residue for stabilization of clays. J. Mater. Civ. Eng. 30(6):04018099.

Lee S, Chung MK, Kim Y, Kee J (2017) Geotechnical shear behavior of Xanthan gum biopolymer treated sand from direct shear testing. Geomech. Eng. 12:831-847

Maignien, R. 1966. Review of Research on Laterites. Natural Resources Research IV. UNESCO, Paris, p.148.

Makusa, GP. 2012. State of the art review of soil stabilization methods and materials. Lulea University of Technology, pp. 1-35. 
Mousavi, S. and Sing, WL. 2015. Utilization of brown clay and cement for stabilization of clay. Jordan Journal of Civil Engineering. 9(2):163-174.

Mujah, D, Ekhlasur, M, and Zain, NHM. 2015. Performance evaluation of the soft soil reinforced ground palm oil fuel ash layer composite. Journal of Clean Prod. 95:89-100.

Nigeria Geological Survey Agency (2006) Geological and Mineral Resources Map of Ondo State. Published by the Authority of the Federal Republic of Nigeria, Nigeria.

Ola SA (1981) Expansive clays in engineering construction, in Lekmang IC, Daku SS Yenne EY, Wazoh HN, Goyit MP (2016) Geotechnical investigations for infrastructural development: a case study of Daki Biyu District, Federal Capital Territory, Abuja, Central Nigeria. J Geol. Mining Res 8(3):28-39.

Olorunfemi, MO., Ojo, JS. and Akintunde, OM. 1999. Hydrogeophysical evaluation of ground water potentials of Akure metropolis, southwestern Nigerian Jour. Min. Geo. 35(2): 207-228.

Onuoha DC, Onwuka SU, Okoye CO (2014) Comparative analysis of the soil geotechnical characteristics of the failed and un-failed sections of the Onitsha-Enugu expressway, southeastern Nigeria. Jour. of Environment \& Earth Science. 4(16):125-133.

Oriola, F and Moses, G. 2010. Groundnut Shell Ash Stabilization of Black Cotton Soil: Electronic Jour: Geotech: Eng: 15, Bund. E, 415-428.

Owoseni JO, Atigro EO (2019) Engineering geological investigation of highway pavement failure in basement complex terrain of southwestern Nigeria. Int. Jour. of Eng. Sc. Invention. 8(6):1422 .

Owoseni, JO. and Atigro, EO. 2014. Use of Agricultural wastes in stabilizing residual tropical soils for road construction. European Int. Jour. Appl. Sc. Tech. 1(5):117-136.

Oyinloye, AO. and Odeyemi, IB. 2001. The geochemistry, tectonic setting and origin of the massive melanocratic amphibolite in the Ilesha Schist Belt, southwestern Nigeria. G. Jour. Pure App. Sci. 7(1), 85-90.

Patel, NA. and Mishra, CB. 2014. Improvement of the strength of inorganic clayey soil using cement additive. International Journal of Current Engineering and Technology. 4(6):42664269 .

Pelliser, F., Pelliser, F., Steiner, LR. and Bernardin, AM. 2015. Pozzolanic effect of porcelain polishing residue in Portland cement. Journal of Clean Production, 100:84-88.

Rashid ASA, Latifi N, Meehan CL, Manahiloh KN (2017) Sustainable improvement of tropical residual soil using an environmentally friendly additive. Geotech Geol. Eng. 35(6):2613-2623

Rashid, ASA., Kueh, ABH. and Mohamad, H. (2018) Behaviour of soft soil improved by floating soil-cement column. Int. J. Phys. Modell. Geotech. 18(2):95-116.

Shankar, QUR., Rai, HK. and Ramesha, MI. 2009. Bio-enzyme stabilized Lateritic soil as a highway material. Jour. Indian Rd. Congress, (553), 143-151.

Tabarsa AR, Latifi N, Meehan CL, Manahiloh KN (2018) Laboratory investigation and field evaluation of loess improvement using nanoclay-A sustainable material for construction. Consr Build Mater 158:454-463 
Tjandra D, Wulandari PS (2007) Improving marine clays with electro-kinetics method. Civ. Eng. Dimens. 9:98-102

Wong LS, Mousavi S, Sobhani S, Kong SY, Birima AH, Mohd Pauzi NI (2016) Comparative measurement of compaction impact of clay stabilized with cement, peat ash and silica sand. Meas J Int Meas Confed 94:498-504

Yaghoubi, M., Arulrajah, A., Disfani, MM., Horpibulsuk, S., Bo, MW. and Darmawan, S. 2018. Effects of industrial by-product based geo-polymers on the strength development of a soft soil. Soils Found. 58(3):716-728.

Yilmaz Y (2015) Compaction and strength characteristics of fly ash and fiber amended clayey soil. Eng Geol 188:168-177. 